\title{
A study on different factors influencing customer satisfaction on industrial market
}

\author{
Alireza Shirani ${ }^{\mathrm{a}}$, Habibollah Danaei ${ }^{\mathrm{b}}$ and Anahita Shirvani ${ }^{* *}$
}

${ }^{a}$ Department of Management and accounting, Allame Tabatabaee University, Tehran, Iran

${ }^{b}$ Department of Management, Payame Nour University, Alborz Unit, Karaj, Iran

${ }^{c}$ Department of Management, Payame Nour University, Tehran West, Tehran, Iran

\section{H R O N I C L E$$
\text { A B S T R A C T }
$$

Article history:

Received Feb 25, 2013

Received in revised format

19 September 2013

Accepted 23 October 2013

Available online

November 182013

Keywords:

Customer satisfaction

Quality of product

Price

Dairy product

\begin{abstract}
Customer satisfaction plays essential role on the success of industrial products such as milk in todays' marketing planning. In this paper, we present a conceptual model to measure the relative impact of various factors on customer satisfaction. The proposed study of this paper designs a questionnaire and distributes it among managers of a dairy producer named Pegah in city of Esfahan, Iran. Using Pearson correlation ratio as well as stepwise regression technique, the study has found positive and meaningful relationship between customer satisfaction and price, quality of product, distribution and compatibility with customer expectation. In addition, the study detects a negative and meaningful relationship between conflict and customer satisfaction.
\end{abstract}

\section{Introduction}

For years, many business owners have attempted to find different methods for measuring customer satisfaction and they have tried to find possible barriers on building mutual trust between their activities and their regular customers in an attempt to have loyal customers (Farris et al., 2010; Cambra-Fierro \& Polo-Redondo, 2008; Hogan, 2001). Loyal customers are considered as the best source for promoting products and services through word-of-mouth advertisement (Yau et al., 2000; O'Sullivan \& Abela, 2007). Therefore, detecting key components for customer satisfaction plays essential role for the success of any organization (Redondo \& Fierro, 2005; Mariussen, 2011). One of the popular methods for having good feedbacks from suppliers is accomplished through customer relationship management (CRM). During the past few years, there have been various studies on CRM issues. Kulmala (2004), for instance, described cost management development projects in three customer-supplier relationships and analyzed these projects from the perspective of relationships. The survey indicated that differences in suppliers' aims, actions taken, and results gained in the

* Corresponding author. Tel:+989133265413

E-mail addresses: ana_sh4000@yahoo.com (A. Shirvani) 
projects could be detected in the explorative study, although the customer's objective was the same in all cases. The implementation of cost information depended on the balance of power between firms, on the trust between personnel, and on the volume of the firms' mutual business. Lee and Johnsen (2012) analyzed the relationship development stages of asymmetric customer-supplier relationships. They linked the characteristics of asymmetric customer-supplier relationships and the relationship development stages through a comprehensive review on the existing literature. Polo-Redondo and Cambra-Fierro (2008) investigated the effect of the standardization of a firm's productive process on the long-term orientation of its supply relationships. Kim et al. (2010) investigated the relationship between consumer complaining behavior and service recovery. $\mathrm{Ng}$ (2012) performed an empirical investigation on the success factors of supplier-distributor relationships. Marketing practitioners are under increasing pressure to express their contribution to firm performance. Therefore, many marketers are investing in the development of performance measurement capabilities (Jain \& Singh, 2002; Sin et al., 2005). O'Sullivan and Abela (2007) examined the effect of ability to measure marketing performance on firm performance based on both primary data collected from senior marketers and secondary data on firm profitability and stock returns. They also explored the impact of ability to measure marketing on marketing's stature within the organization and reported that the ability to measure marketing performance could significantly influence on firm performance, profitability, stock returns, and marketing's stature within the firm.

Jamalizadeh et al. (2013) applied fuzzy analytical network process (FANP) to rank various factors in the context of customer satisfaction in hospitals by considering four major criteria including employee, management as well as organization, physicians and nurses. The survey indicated that management and organizational issues were the most important factors followed by issues associated with physicians, nurses and employees. In terms of management and organization in their survey, waiting time to receive services was the most important factor followed by geographic location of the hospital, peaceful and quiet environment and quality of services. Hassani et al. (2013) performed an investigation on the effects of knowledge management on the success of customer relationship management and reported that knowledge impacted CRM positively in terms of customer satisfaction, customer loyalty and trust. Ryals and Knox (2001) investigated the cross-functional issues in the implementation of relationship marketing through customer relationship management. Khodakarami and Chan (2014) explored how customer relationship management (CRM) systems could support customer knowledge creation processes, including socialization, externalization, combination and internalization. In this survey, CRM systems were categorized as collaborative, operational and analytical and the authors reported that analytical systems could strongly support the combination process. Collaborative systems could provide the biggest support for externalization. Operational systems facilitated socialization with customers, while collaborative systems were applied for socialization within a firm. Collaborative and analytical systems both supported the internalization process by providing learning opportunities.

Piercy (2009) concentrated on the potential effect of enhanced strategic relationships between the boundary-spanning functions in supplier organizations. The primary objective of this survey was associated with alignment between the organizational groups managing including marketing, sales and strategic account management; purchasing and supply strategy; and, collaborations and external partnerships. The topic was framed by the organizational evolution being driven by market change, and the investigation was for superior innovation capabilities and business agility. The integration of CRM and supplier relationship management (SRM) to facilitate supply chain management in the areas of supplier selection using a help desk facilities has become a promising solution for manufacturers to detect suitable suppliers and trading partners to form a supply network on which they depend for products, services, and distribution. Choy et al. (2002) discussed an intelligent customer-supplier relationship management system (ISRMS) based on the case based reasoning (CBR) technique to select potential suppliers. They reported that the outsource cycle time from the searching of potential suppliers to the allocation of order could be greatly reduced. 


\section{The proposed}

We present a conceptual model to measure the relative impact of various factors on customer satisfaction. The proposed study of this paper designs a questionnaire and distributes it among managers of a dairy producer named Pegah in city of Esfahan, Iran. The paper is adapted from the existing works on the literature (Sanzo, 2003; Skarmeas et al., 2008; Sila et al., 2006). The proposed model of this paper considers the following hypotheses (See also Fig. 1),

1. Suppliers' appropriate prices influence positively on relationship with producer.

2. Suppliers' high quality products influence positively on relationship with producer.

3. Suppliers' on time and appropriate delivery influence positively on relationship with producer.

4. Suppliers' appropriate communication influence positively on relationship with producer.

5. Building a good trust with suppliers influence positively on relationship with producer.

6. Offering good services with suppliers influence positively on relationship with producer.

7. Suppliers meeting producers' expectations influence positively on relationship with producer.

8. Existence of conflict influence positively on relationship with producer.

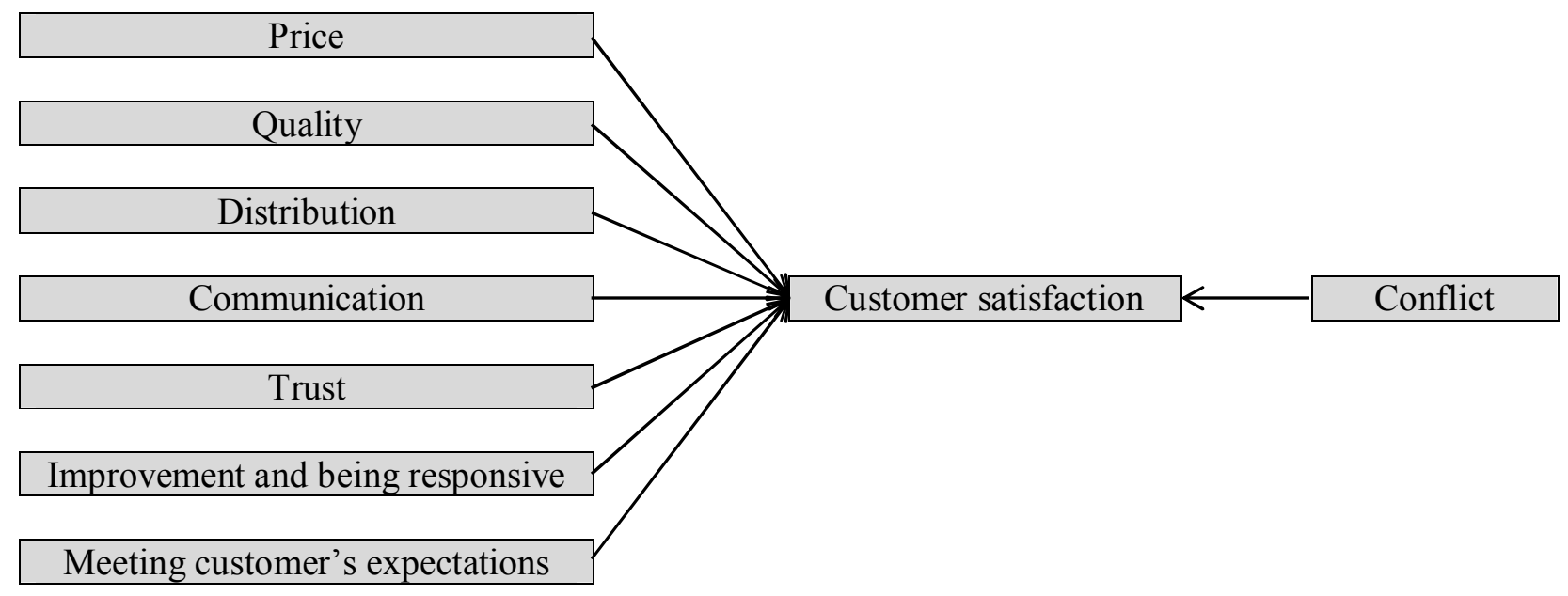

Fig. 1. The proposed study

As we can observe, there are eight hypotheses associated with the proposed study of this paper. There were 30 people who were acting as managers for the proposed case study of this paper where 28 of them were male and 2 were female. In addition, there were 7 top managers and 23 middle managers. Fig. 2 demonstrates other characteristics of the participants.

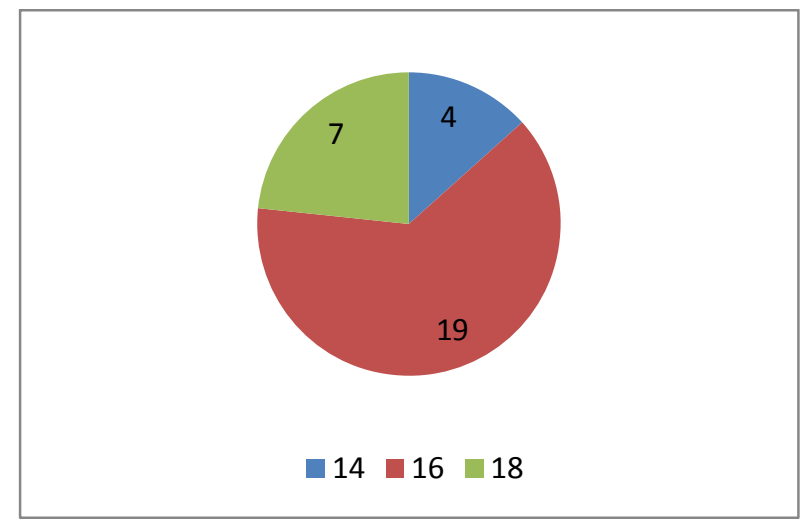

Years of education

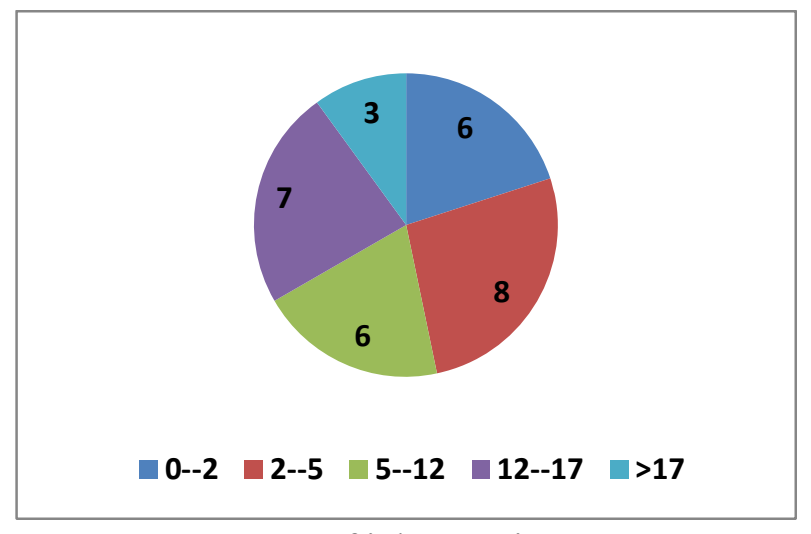

Years of job experience

Fig. 2. Personal characteristics of the participants 
As we can observe from the results of Fig. 2, most participants in our survey hold a master degree of science. In addition, they maintained some job experiences, which means they were familiar with different suppliers and their contribution could lead us to reach appropriate results. Next, we present details of the implementation of Pearson correlation as well as stepwise regression.

\section{The results}

In this section, we present details of our findings on testing various hypotheses of the survey.

\subsection{The results of Pearson correlation}

We first present correlation ratios between producer's satisfaction and different factors. Table 1 shows details of correlations.

\section{Table 1}

The summary of correlations among various factors

\begin{tabular}{lcccc}
\hline Variable & $\mathrm{R}$ & $\mathrm{R}^{2}$ & Adjusted R $^{2}$ & Standard deviation \\
\hline Price & 0.527 & 0.277729 & 0.252 & 0.46116 \\
Quality & 0.591 & 0.349281 & 0.326 & 2.33586 \\
Distribution & 0.4 & 0.16 & 0.13 & 2.65459 \\
Communication & 0.18 & 0.0324 & -0.002 & 1.76527 \\
Trust & 0.656 & 0.430336 & 0.41 & 2.18619 \\
Responsiveness & 0.116 & 0.013456 & -0.022 & 2.87619 \\
Expectations & 0.646 & 0.417316 & 0.396 & 2.21124 \\
Conflict & -0.429 & 0.184041 & 0.155 & 2.61533 \\
\hline
\end{tabular}

As we can observe from the results of Table 1, there are positive and meaningful relationship between price, quality, distribution, trust and expectations on one side and producers' satisfaction from suppliers.

\subsection{The results of stepwise regression and ANOVA test}

Since there were some positive and meaningful relationship between independent variables and customer satisfaction, we have performed regression analysis and Table 2 shows details of ANOVA test.

Table 2

The summary of ANOVA test

\begin{tabular}{lccccc}
\hline Variable & Sum of squares & df & Mean of squares & F-value & Sig. \\
\hline Price & 65.195 & 1 & 65.195 & 10.763 & 0.003 \\
Quality & 82.026 & 1 & 82.026 & 15.033 & 0.001 \\
Distribution & 37.488 & 1 & 37.488 & 5.32 & 0.029 \\
Communication & 2.914 & 1 & 2.914 & 0.935 & 0.342 \\
Trust & 100.975 & 1 & 100.975 & 21.127 & 0 \\
Responsiveness & 3.171 & 1 & 3.171 & 0.383 & 0.541 \\
Expectations & 97.892 & 1 & 97.892 & 20.021 & 0 \\
Conflict & 43.282 & 1 & 43.282 & 6.328 & 0.018 \\
\hline
\end{tabular}

As we can observe from the results of Table 2, F-value for price, quality, trust, expectation and conflict is significant. Therefore, we can use regression analysis and the results are given in Table 3. The results of Table 3 clearly indicate that price, quality, distribution, trust, expectations and conflict have meaningful impact on customer satisfaction where the effects of the first five variables are positive and conflict has negative impact on customer satisfaction. 
Table 3

The summary of regression analysis

\begin{tabular}{lccccc}
\hline Variable & Non-standard & Standard error & Standard value & t-value & Sig. \\
\hline Price & 0.815 & 0.248 & 0.527 & 3.281 & 0.003 \\
Quality & 0.954 & 0.246 & 0.591 & 3.877 & 0.001 \\
Distribution & 0.658 & 0.285 & 0.400 & 2.306 & 0.029 \\
Communication & 0.224 & 0.232 & 0.180 & 0.967 & 0.342 \\
Trust & 0.613 & 0.133 & 0.656 & 4.596 & 0 \\
Responsiveness & 0.337 & 0.545 & 0.116 & 0.619 & 0.541 \\
Expectations & 0.760 & 0.170 & 0.646 & 4.474 & 0 \\
Conflict & -0.652 & 0.259 & -0.429 & -2.516 & 0.018 \\
\hline
\end{tabular}

\section{Conclusion}

In this paper, we have presented an empirical investigation to study the effects of eight variables on relationship between suppliers and producers in dairy products. The proposed method of this paper has implemented Pearson correlation as well as regression analysis to study the relationships between customer satisfaction as dependent variable and different independent variables. The results of Pearson correlation have indicated that there were positive and meaningful relationship between price, quality, distribution, trust and expectations on one side and producers' satisfaction from suppliers. In addition, the results of stepwise regression have indicated that price, quality, distribution, trust, expectations and conflict had meaningful impact on customer satisfaction. The effects of the first five variables were positive and conflict had negative impact on customer satisfaction.

\section{Acknowledgment}

The authors would like to thank the anonymous referees for their comments on earlier version of this paper.

\section{References}

Ambler, T., \& Puntoni, S. (2003). Measuring marketing performance. Marketing Changes, 289-309.

Choy, K.L., Lee, W.B ., \& Lo, V. (2002). Development of a case based intelligent customer-supplier relationship management system. Expert Systems with Applications, 23(3), 281-297.

Cambra-Fierro, J. J., \& Polo-Redondo, Y. (2008). Creating satisfaction in the demand-supply chain: the buyers' perspective. Supply Chain Management: An International Journal, 13(3), 211-224.

Farris, P. W., Bendle, N. T., Pfeifer, P. E., \& Reibstein, D. J. (2010). Marketing metrics: The definitive guide to measuring marketing performance. Pearson Education.

Hassani, M., Aghaalikhani, E., Hassanabadi, M \& Rad, M. (2013). A study on effects of knowledge management on the success of customer relationship management. Management Science Letters, 3(9), 2431-2436.

Hogan, J. E. (2001). Expected relationship value: a construct, a methodology for measurement, and a modeling technique. Industrial Marketing Management,30(4), 339-351.

Mariussen, A. (2011). Rethinking marketing performance measurement: Justification and operationalisation of an alternative approach to affiliate marketing performance measurement in tourism. e-Review of Tourism Research, 9(3), 65-87.

Jamalizadeh, Z., Meshkani, F \& Naami, A. (2013). A study on factors influencing customer satisfaction: A case study of hospital dialysis patients. Management Science Letters, 3(10), 26032608.

Jain, D., \& Singh, S. S. (2002). Customer lifetime value research in marketing: A review and future directions. Journal of Interactive Marketing, 16(2), 34-46. 
Kim, M. G., Wang, C., \& Mattila, A. S. (2010). The relationship between consumer complaining behavior and service recovery: an integrative review. International Journal of Contemporary Hospitality Management, 22(7), 975-991.

Khodakarami, F., \& Chan, Y.E. (2014). Exploring the role of customer relationship management (CRM) systems in customer knowledge creation. Information \& Management, 51(1), 27-42.

Kulmala, H.I. (2004). Developing cost management in customer-supplier relationships: three case studies. Journal of Purchasing and Supply Management, 10(2), 65-77.

Lee, C.J., \& Johnsen, R.E. (2012). Asymmetric customer-supplier relationship development in Taiwanese electronics firms. Industrial Marketing Management, 41(4), 692-705.

$\mathrm{Ng}$, E. (2012). An empirical study on the success factors of supplier-distributor relationships. Contemporary Management Research, 8(2), 161-180.

O'Sullivan, D., \& Abela, A. V. (2007). Marketing performance measurement ability and firm performance. Journal of Marketing, 71(2), 79-93.

Piercy, N.F. (2009). Strategic relationships between boundary-spanning functions: Aligning customer relationship management with supplier relationship management. Industrial Marketing Management, 38(8), 857-864.

Polo-Redondo, Y., \& Cambra-Fierro, J. (2008). Influence of the standardization of a firm's productive process on the long-term orientation of its supply relationships: An empirical study. Industrial Marketing Management, 37(4), 407-420.

Redondo, Y. P., \& Fierro, J. J. C. (2005). Moderating effect of type of product exchanged in longterm orientation of firm-supplier relationships: an empirical study. Journal of Product \& Brand Management, 14(7), 424-437.

Ryals, L., \& Knox, S. (2001). Cross-functional issues in the implementation of relationship marketing through customer relationship management. European Management Journal, 19(5), 534-542.

Sin, L. Y., Alan, C. B., \& Yim, F. H. (2005). CRM: conceptualization and scale development. European Journal of Marketing, 39 (11/12), 1264-1290.

Sanzo, M. J., Santos, M. L., Vázquez, R., \& Álvarez, L. I. (2003). The effect of market orientation on buyer-seller relationship satisfaction. Industrial Marketing Management, 32(4), 327-345.

Sila, I., Ebrahimpour, M., \& Birkholz, C. (2006). Quality in supply chains: an empirical analysis. Supply Chain Management: An International Journal, 11(6), 491-502.

Skarmeas, D., Katsikeas, C. S., Spyropoulou, S., \& Salehi-Sangari, E. (2008). Market and supplier characteristics driving distributor relationship quality in international marketing channels of industrial products. Industrial Marketing Management, 37(1), 23-36.

Yau, O. H., Lee, J. S., Chow, R. P., Sin, L. Y., \& Tse, A. C. (2000). Relationship marketing the Chinese way. Business Horizons, 43(1), 16-24. 